${ }^{23}$ Lassen NA. Control of cerebral circulation in health and disease. Circ Res $1974 ; 34: 749-60$

${ }^{24}$ Gilroy J, Meyer SJ. Medical neurology, 3rd ed. New York: McMillan Publishing Co, 1979:545.

25 Nelson D, Fazekas JF. Cerebral blood flow in polycythaemia vera. Arch Intern Med 1956;98:328-31.

${ }^{26}$ Thomas DJ, du Boulay GH, Marshall J, et al. Cerebral blood flow in polycythaemia. Lancet 1977 ;ii:161-3.

${ }^{27}$ Heyman A, Patterson JL, Duke TW. Cerebral circulation and metabolism in sickle cell and other chronic anaemias, with observations on the effects of oxygen inhalation. $\mathcal{F}$ Clin Invest $1952 ; 31: 824-8$.

28 Gottstein U, Held K. The effect of haemodilution caused by low molecular weight dextran on human cerebral blood flow and metabolism. In: Brock M, Fieschi C, Ingvar DH, et al, eds. Cerebral blood flow. Berlin, Heidelberg, New York: Springer, 1969:104-5.

29 Heiss W-D, Prosenz P, Tschabitscher H, Lasek C, Herles HJ. Effect of low molecular dextran on total cerebral blood flow and on regional flow within ischemic brain lesions. Eur Neurol 1972;8:129-33.
${ }^{30}$ Kety SS, Schmidt CF. The effects of altered arterial tensions of carbon dioxide and oxygen on cerebral blood flow and cerebral oxygen consumption of normal young men. $\mathcal{F}$ Clin Invest $1948 ; 27: 484-92$.

${ }^{31}$ Paulson OB, Parving HH, Olesen J, Skinhøj E. Influence of carbon monoxide and of hemodilution on cerebral blood flow and blood gases in man. F Appl Physiol 1973;35:111-6.

${ }^{32}$ Meyer JS, Shimazu R, Fukuuchi Y, et al. Impaired neurogenic cerebrovascular control and dysautoregulation after stroke. Stroke 1973;4: 169-86.

${ }^{33}$ McHenry LC, West JW, Cooper ES, et al. Cerebral autoregulation in man. Stroke $1974 ; 5: 695-706$

${ }^{34}$ Harrison MJG, Pollock S, Kendall BE, Marshall J. Effect of haematocrit on carotid stenosis and cerebral infarction. Lancet 1981 ;i:114-5.

${ }^{35}$ Høedt-Rasmussen $\mathrm{K}$, Skinhøj E, Paulson $\mathrm{O}$, et al. Regional cerebral blood flow in acute apoplexy. Arch Neurol 1967;17:271-81.

(Accepted 11. March 1982)

\title{
Effect of transdermally administered hyoscine methobromide on nocturnal acid secretion in patients with duodenal ulcer
}

\author{
R P WALT, C J KALMAN, R H HUNT, J J MISIEWICZ
}

\begin{abstract}
Use of anticholinergic drugs in treatment of duodenal ulcers is limited by the side effects of widespread parasympathetic blockade evoked by usual therapeutic doses. A study was conducted into the effectiveness of transdermal delivery of hyoscine methobromide using a new system which releases the drug into the circulation at a controlled rate. In six patients whose duodenal uilcer had healed secretion of acid was measured over two nights, the first on placebo and the second on hyoscine methobromide. All patients responded to the active drug and showed a significant inhibition of acid secretion. Four subjects complained of a dry mouth after overnight treatment with hyoscine methobromide; no other side effects were reported.
\end{abstract}

Transdermal delivery of anticholinergic drugs may be useful in maintenance treatment of duodenal ulcers and further clinical tests are indicated.

\section{Introduction}

Anticholinergic drugs have been used extensively in the treatment of duodenal ulcers, but less so after the introduction of derivatives of liquorice and histamine $\mathrm{H}_{2}$-receptor antagonists ${ }^{1-3}$ and the renewal of interest in complexed bismuth." Though anticholinergics decrease basal, nocturnal, and stimulated acid output in patients with and without duodenal ulcers, ${ }^{156}$ their use is severely limited by side effects of widespread para-

Department of Gastroenterology, Central Middlesex Hospital, London NW10 7NS

R P WALT, MB, MRCP, research fellow and honorary registrar (present address: Academic Department of Medicine, Royal Free Hospital, London NW3 2QG)

J J MISIEWICZ, MB, FRCP, consultant physician

Royal Naval Hospital, Haslar, Hants

C J KALMAN, MB, CHB, surgeon lieutenant

R H HUNT, MB, FRCP, consultant physician and gastroenterologist sympathetic blockade evoked by the usual therapeutic doses. These effects may be produced by blood concentrations of anticholinergics that exceed the concentrations necessary for gastric secretory inhibition, but they are inescapable if drugs are administered in conventional tablet form. We report on an anticholinergic drug (hyoscine methobromide) given using a new transdermal therapeutic system ${ }^{2}$ (Transderm V, CIBA Pharmaceutical Company) that delivers the drug into the circulation at a controlled, predetermined rate. This treatment effectively inhibited nocturnal secretion of acid in patients with duodenal ulcer.

\section{Patients and methods}

Transdermal therapeutic system is a multilayer laminate $2.5 \mathrm{~cm}^{2}$ in area and $200 \mu \mathrm{m}$ thick (fig 1 ). The system comprises a drug reservoir containing hyoscine methobromide in a polymeric gel, surrounded by an impermeable backing membrane and a microporous membrane, which controls the rate of release. It is fastened to the skin by an adhesive layer, which also acts as a reservoir for a priming dose of hyoscine methobromide. The microporous membrane allows hyoscine methobromide to be released at a constant rate of $4 \mu \mathrm{g} / \mathrm{cm}^{2} / \mathrm{h}$ and delivers $0.5 \mathrm{mg}$ of hyoscine methobromide at a steady rate for $72 \mathrm{~h}$. The system was worn by the patients behind the ear, as studies have shown the skin in this region to be most permeable to hyoscine methobromide.

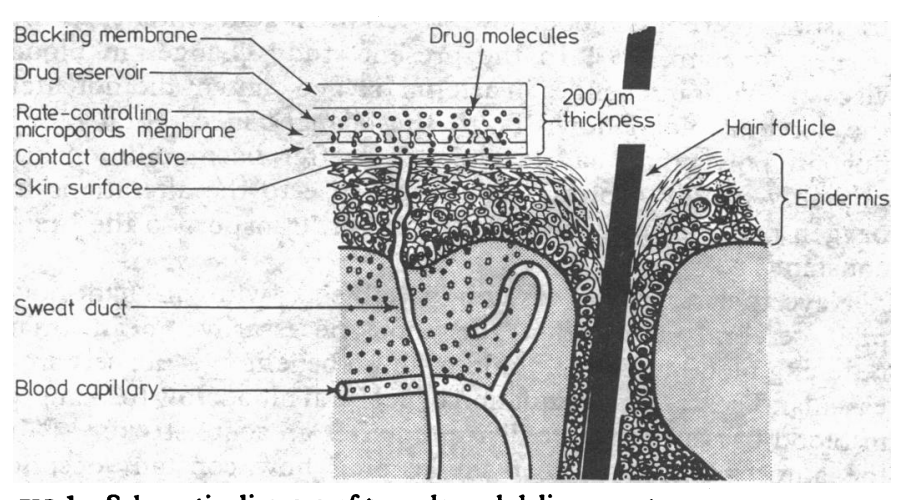

FIG 1-Schematic diagram of transdermal delivery system. 
Six men with duodenal ulcer in remission (age range 21-40 years, mean 31.2 years) were admitted to a special unit and studied on two consecutive nights. At midday each day the area behind the left ear was cleaned and placebo (first night) or hyoscine methobromide (second night) applied to the skin. At 1700 the patients were intubated with a $10-G$ Salem sump tube (Argyle Medical). Patients ate standard meals on both study days at 1300 and 1800 with only water allowed thereafter. Stomach contents were aspirated and discarded at 2300 and gastric secretion was then collected hourly until 0800 by pump suction, aided when required by syringe aspiration. Five-ml aliquots of each hourly collection were used to measure $\mathrm{pH}$ and titrate with $0 \cdot 1 M \mathrm{NaOH}$ to $\mathrm{pH} 7 \cdot 0$, using an automatic titrator (Radiometer, Copenhagen). $\mathrm{pH}$ electrodes were calibrated between each determination with standard buffers.

All patients were questioned each morning about unwanted effects. Results were expressed in terms of mean hourly acid output in $\mathrm{mmol} / \mathrm{h}$ and in mean hourly hydrogen ion $\left(\mathrm{H}^{+}\right)$concentrations in mmol/l. Wilcoxon's signed rank test and Student's $t$ test for paired samples were used for statistical analysis. Informed consent was obtained from all subjects and the study was approved by the local ethical committees.

\section{Results}

Gastric aspirates were technically unsatisfactory in one subject and he was excluded from analysis. In the remaining five patients the mean hourly (2300-0800) acid output decreased from $6.8 \pm 1.8 \mathrm{mmol} / \mathrm{h}$ (mean $\pm S E M$ ) on placebo to $1 \cdot 7 \pm 0.4 \mathrm{mmol} / \mathrm{h}$ when hyoscine methobromide was used. This $75 \%$ inhibition of acid secretion was

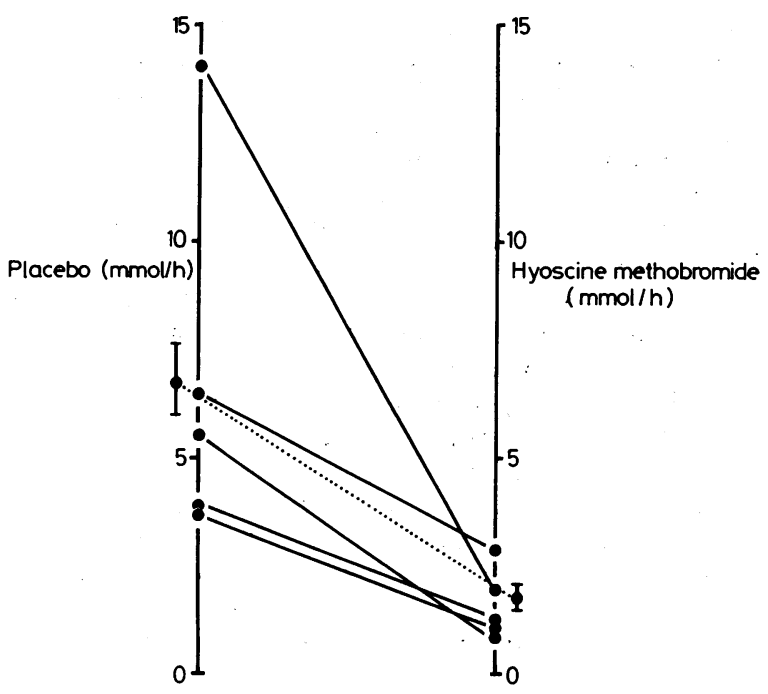

FIG 2-Individual and mean overnight acid outputs (2400-0800) with transdermal delivery of placebo and hyoscine methobromide. Dotted line and bars represent mean \pm SEM.

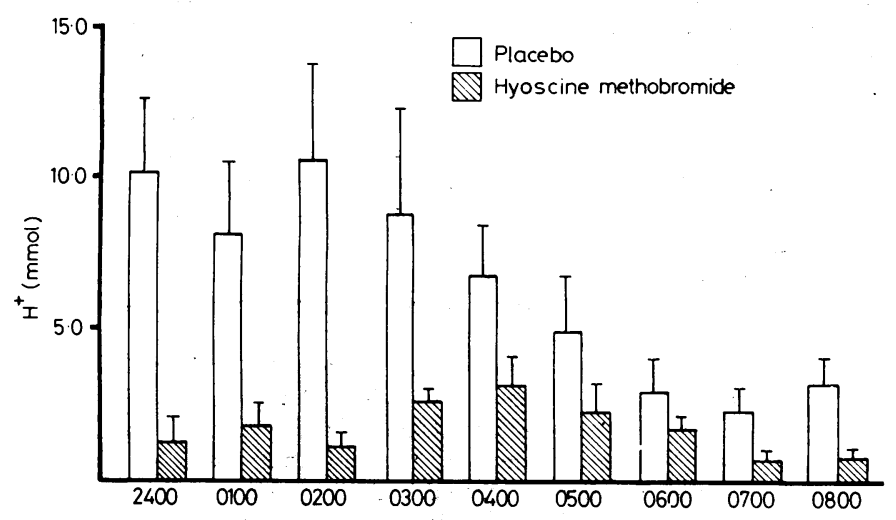

FIG 3-Mean ( \pm SEM) hourly acid secretion of acid for each hourly collection 2400-0800 (five patients). significant ( $p<0.001$, figs 2 and 3). All the patients responded to hyoscine methobromide administered via the transdermal therapeutic system (fig 2). The $\mathrm{H}^{+}$concentration was unaffected $(79 \cdot 1 \pm 6 \cdot 4$ $\mathrm{mmol}(\mathrm{mEq}) / 1$ on placebo, $68.2 \pm 3.5 \mathrm{mmol} / \mathrm{l}$ on hyoscine methobromide).

Four of the subjects reported a dry mouth after overnight hyoscine methobromide and one of them also noticed this shortly after the transdermal therapeutic system was applied to the skin. There were no other side effects.

\section{Discussion}

These results suggest that transdermal delivery of hyoscine methobromide at about $5 \mu \mathrm{g} / \mathrm{h}$ significantly inhibits nocturnal secretion of acid in patients with duodenal ulcer. Others have shown that basal daytime output of acid may also be significantly decreased by transdermal delivery of hyoscine methobromide. ${ }^{8}$ The transdermal therapeutic system delivers the drug at a steady rate over 72 h. ${ }^{9}$ The relapse rate of healed duodenal ulcers may be significantly decreased by the nightly administration of cimetidine $400 \mathrm{mg}$, which inhibits overnight secretion of acid.10 This system is therefore potentially useful as a maintenance treatment for healed duodenal ulcers, either alone or in combination with a smaller than usual dose of histamine $\mathrm{H}_{2}$-receptor blocking drugs. The ease of a schedule of three-day administration is especially attractive.

Transdermal delivery of hyoscine methobromide effectively prevents the symptoms of natural or experimentally induced motion sickness. ${ }^{11} 12$ Effects of hyoscine methobromide on daytime acid output - for example, stimulated by meals - are not yet knnwn, but it would seem reasonable to explore its potential in the short-term healing of duodenal ulcers.

Four patients complained of dry mouth. Previous data suggest, however, that in larger numbers of non-intubated subjects the incidence of this side effect is low and transient ${ }^{11-13}$ : wider use will determine whether this side effect is troublesome.

Other observations recorded in this study deserve mention. Firstly, some patients do not respond to $\mathrm{H}_{2}$-blockade. ${ }^{14}$ Cimetidine had previously failed to inhibit nocturnal secretion of acid in one patient in this study whose overnight acid output was decreased by $88 \%$ with hyoscine methobromide. Secondly, though acid output decreased significantly, the $\mathrm{pH}$ concentration was unaffected and gastric bacterial colonisation should not therefore be a problem with transdermal delivery of hyoscine methobromide. ${ }^{15}$ Thirdly, the gastric juice collections contained no mucus, contrasting with the appearance of gastric juice collected during histamine $\mathrm{H}_{2}$-blockade. Cholinergic agents stimulate mucus secretion in the human alimentary tract, ${ }^{16}$ so that this observation should be further evaluated if hyoscine methobromide is used for prolonged periods. Further clinical testing of transdermal delivery of hyoscine methobromide, or perhaps a more specific anticholinergic agent such as pirenzepine, ${ }^{17}$ is indicated.

We thank Dr J Urquhart and Dr Jane E Shaw of Alza Corporation, Palo Alto, California, USA for supplies of hyoscine methobromide; the medical and administrative staff of the Royal Naval Hospital, Haslar for facilities; and Ms P Evans for secretarial help.

\section{References}

1 Ivey KJ. Anticholintergics: do they work in peptic ulcer ? Gastroenterology 1975;68:154-66.

2 Burland WL, Simkins MA, eds. Cimetidine. Proceedings of the second international symposium on histamine $H_{2}$-receptor antagonists. Amsterdam: Excerpta Medica, 1977.

3 Pinder RM, Brogden RN, Sawyer PR, Speight TM, Spencer R, Avery GS. Carbenoxolone: a review of its pharmacological properties ard therapeutic efficacy in peptic ulcer disease. Drugs 1976;11:245-307.

4 Brogden RN, Pinder RM, Sayer PR, Speight TM, Avery GS. Tripotassium di-citrato bismuthate: a report on its pharmacological properties and therapeutic efficacy in peptic ulcer. Drugs 1976;12:401-11.

5 Walan W. Studies on peptic ulcer disease with special reference to the effects of 1-hyoscyamine. Acta Med Scand 1970;516,suppl:1-57. 
6 Nicol BR. Control of gastric acidity in peptic ulcer. Lancet 1939;ii:881-4.

7 Shaw JE, Chandrase Karan SK. Transdermal therapeutic systems. In: Prescott LF, Nimmo WS, eds. Drug absorption. New York: Adis Press, 1981:186-93.

${ }^{8}$ Bieck PR, Antonin K-H. Inhibition of basal acid secretion by transdermal application of scopolamine in healthy volunteers. Zeitschrift für Gastroenterologie (in press).

9 Shaw J, Urquhart J. Programmed systemic drug delivery by the transdermal route. TIPS 1980, April:208-11.

${ }^{10}$ Burland WL, Hankins BW, Horton RJ, Beresford J. The longer-term treatment of duodenal ulcer with cimetidine. In: Wastell C, Lance P, eds. Cimetidine. Edinburgh: Churchill Livingstone, 1978:77-82.

11 Price N, Schmitt LG, Shaw JE. Transdermal delivery of scopolamine for prevention of motion induced nausea in rough seas. Clinical Therapeutics $1979 ; 2: 258-62$.

12 Graybiel A, Knepton J, Shaw J. Prevention of experimental motion sickness by scopolamine absorbed through the skin. Aviat Space Environ Med 1976;47:1096-110.

${ }^{13}$ McCauley ME, Royal JW, Shaw JE, Schmitt LG. Effect of transdermally administered scopolamine in preventing motion sickness. Aviat Space 0 Environ Med 1979;50:1108-111.

14 Hunt RH, Melvin MA, Mills JG. Gastric function after treatment with cimetidine. In: Torsok A, Luchelli PE, Brimblecombe RW, eds. ® Further experience with $\mathrm{H}_{2}$-receptor antagonists in peptic ulcer disease and $C$ progress in histamine research. Amsterdam: Excerpta Medica, 1980:11926.

${ }^{26}$ Deane SA, Gatehouse D, Young DJ, Burdon DW, Alexander Williams J, Keighley MRB. Bacterial flora of the postoperative stomach. Gut 1979;20:A931-2.

16 Glass GBJ, Boyd LJ. The influence of vagotropic and sympathicotropic stimuli on the secretion of gastric mucin and its fractions in man. $A m \mathcal{F} \Omega$ Dig Dis 1950;17:355-61.

17 Chierichetti SM, Gastani M, Petrin G. Pharmacokinetic and clinical $\overline{\bar{B}}$ studies on pirenzepine, a new anti-ulcer drug. Scand $\mathcal{f}$ Gastroenterol 1979;14,suppl $57: 7-10$.

\title{
Predictive value of SS-B precipitating antibodies in Sjögren's syndrome
}

\author{
D A ISENBERG, \\ LINDA HAMMOND, \\ C FISHER, \\ MERYL GRIFFITHS, JANE STEWART, \\ G F BOTTAZZO
}

\begin{abstract}
As part of a screening programme several patients were identified with antibodies to the nuclear antigen SS-B. Fifteen were examined and 11 found to have Sjögren's syndrome, though this had not been suspected by most of the referring physicians. In contrast, among a group of 17 patients with overt Sjögren's syndrome, most of whom also had rheumatoid arthritis, only one had antibodies to SS-B. Patients presenting with polyarthralgia found to be SS-B positive may be likely to develop Sjögren's syndrome but unlikely to develop rheumatoid arthritis. The detection of SS-B antibodies may antedate clinical evidence of Sjögren's syndrome by months or even years.
\end{abstract}

These results emphasise the clinical heterogeneity of Sjögren's syndrome.

\section{Introduction}

Sjögren's syndrome is an autoimmune disease characterised by a pronounced infiltration of lymphocytes and plasma cells into the salivary and lacrimal glands. ${ }^{12}$ Features of its autoimmunity include the frequent presence of hypergammaglobulinaemia ( $50 \%$ of cases), rheumatoid factor $(75-90 \%$ of cases), and antinuclear antibody (up to $80 \%$ of cases). ${ }^{2}$ Less common findings include the presence of antibodies to DNA, salivary duct tissue, smooth muscle, mitochondria, thyroglobulin, thyroid microsomes, and gastric parietal cells. ${ }^{1-4}$

Departments of Rheumatology, Morbid Anatomy, and Oral Surgery, University College Hospital, London

D A ISENBERG, MRCP, senior registrar, rheumatology department

C FISHER, MRCPATH, senior lecturer, morbid anatomy department (now consultant histopathologist, Brompton Hospital, London)

MERYL GRIFFITHS, MB, BS, lecturer, morbid anatomy department

JANE STEWART, BCHD, clinical lecturer, oral surgery department

Department of Immunology, Middlesex Hospital Medical School, London W1P 9PG

LINDA HAMMOND, BSC, research assistant

G F BOTTAZZO, MD, MRCPATH, senior lecturer in clinical immunology
In the past five years it has also been shown that some patients with Sjögren's syndrome develop antibodies to the recently $\vec{N}$ described nuclear antigens SS-A and SS-B. ${ }^{5}$ The nomenclature has become confused as other groups have identified similar $\overparen{\Phi}$ antibodies but given them different names. SS-A seems to correspond to the Ro antigen described by Reichlin ${ }^{2}$ and SS-B to both the so-called $\mathrm{La}$ and $\mathrm{Ha}$ antigens. ${ }^{6}{ }^{7}$ Of the two, SS-B has been more closely associated with Sjögren's syndrome. ${ }^{2}$

Most of the reports linking SS-B antibodies with Sjögren's syndrome have concentrated on patients in whom the diagnosis was well established. We have studied a population who were known to be SS-B positive but whose accompanying diseases were not initially fully known. We were particularly interested to see whether finding antibodies to SS-B might be of predictive value so far as an underlying diagnosis of Sjögren's syndrome was concerned. Sera from patients with rheumatoid arthritis, systemic lupus erythematosus, and polyendocrine syndromes who had no evidence of Sjögren's syndrome were used as controls. In addition to assessing their sera for antibodies to SS-B we also tested for a panel of other autoantibodies.

\section{Patients and methods}

In the past two years 55 patients whose sera showed speckled anti- O nuclear antibody (ANA) by indirect immunofluorescence were $D$ identified as having SS-B antibodies by counterimmunodiffusion. 을 Fifteen of these patients agreed to undergo examination to see if the $\mathrm{N}$ antibodies correlated with the presence of Sjögren's syndrome. This was diagnosed on the basis of their having (a) four or more of the $\omega$ symptoms of Sjögren's syndrome described by Anderson et $a l^{8} ;(b)$ a positive Schirmer's test result (the filter paper strips (Clement Clarke, 0 London) being damped to less than $10 \mathrm{~mm}$ after challenge with smelling $\frac{\bar{D}}{\mathrm{C}}$ salts for five minutes); (c) a positive labial biopsy appearance (graded $\stackrel{?}{?}$ 3 or 4 according to the criteria of Chisolm and Mason ${ }^{9}$ ).

A detailed medical history of these 15 patients was obtained from their referring physicians, who also gave written permission for their patients to be studied.

Sera from a further 17 patients with Sjögren's syndrome, who had $₫$ already been diagnosed in the rheumatology department at University College Hospital, were also studied. All of these patients also met the $\bigcirc$ above criteria. All were women and their mean age was $64 \pm$ (SD) $9 \cdot 7$ 음 years. Twelve also had rheumatoid arthritis, one with renal tubular acidosis, one with fibrosing alveolitis, and one with hypothyroidism; 윽 one had systemic sclerosis; two had polyarthralgia of uncertain cause; 